\title{
PEREMPUAN DALAM MODERNISME DAN POSTMODERNISME
}

\author{
Budi Rajab \\ Jurusan Antropologi, Fakultas Ilmu Sosial dan Ilmu Politik, \\ Universitas Padjadjaran
}

\begin{abstract}
ABSTRAK. Modernisme telah menerima dan mendorong perempuan untuk bisa berkiprah di sektor publik, tetapi sekaligus ia pun dituntut agar tetap dapat berkiprah di sektor rumah tangga. Konsekuensinya, gerakan perempuan yang terpengaruh dan mengikuti arus modernisasi, aliran feminisme liberal, malah menjadikan perempuan itu sendiri terbebani peran ganda. Gerakan feminisme liberal telah dapat meningkatkan pengetahuan dan kemampuan produktif perempuan di domain publik, tetapi belum bisa mengubah ketimpangan gender itu sendiri. Bagi gerakan perempuan yang berorientasi posmodernisme, konsekuensi dari beban peran ganda perempuan dan tetap berlangsungnya ketimpangan gender merupakan hal yang pasti akan terjadi, karena modernisme itu sendiri merupakan produk kekuasaan patriarkhi. Untuk itulah, kaum feminisposmodernisme menyatakan, supaya gerakan perempuan efektif dan membuahkan hasil berupa kesetaraan gender, sudah harus sejak awal melakukan dekonstruksi atas wacana modernisme itu dan membangun wacana yang bersumber dari pengalaman-pengalaman hidup perempuan itu sendiri.
\end{abstract}

Kata kunci: Modernisme, Gerakan Perempuan, Feminisme Liberal, Posmodernisme

\section{WOMEN IN MODERNISM AND POSTMODERNISM}

\begin{abstract}
Modernism has accepted and encouraged women to take roles in public domain, but they are required to take responsibility on all their household chores. As a consequence, the women's movement, which is influenced and driven by modernism, the liberal feminism stream, in turn would make women be forced to take double roles. Therefore, although liberal feminism movement has raised the level of knowledge and productive ability of women in public domain, it cannot change the gender inequality itself. In the womens movement, which has an orientation towards postmodernism, women's double roles and gender inequality will undeniably occur, because the modernism itself is the product of patriarchy supremacy. For that reason, the peoples of postmodernism-feminist state that in order for the womens movement to be effective and be resulted in gender equality, it is necessary from the very beginning to deconstruct that postmodernism discourse and to build a discourse that is rooted in the experiences of the women themselves.
\end{abstract}

Keywords: Modernism, Women Movement, Liberal Feminism, Postmodernism 


\section{PENDAHULUAN}

Secara biologis, laki-laki dan perempuan berbeda. Perbedaan itu menunjuk pada perbedaan jenis kelamin (sex) yang kodrati. Namun demikian, secara historis dan nampaknya juga masih berlaku hingga sekarang, masyarakat kemudian memapankan dan memperluas perbedaan kodrati tersebut melalui stereotypes dan prasangka-prasangka psikologis tertentu, dan malah selanjutnya dalam posisi sosial pun dibedakan dan dipisahkan. Dianggap, bahwa ciri-ciri fisik-biologis yang melekat pada perempuan menjadikan ia jauh lebih lemah dan kemudian juga hal itu merefleksikan karakteristik kejiwaan atau identitas mental yang pasif, emosional, submisif, dan permisif. Sebaliknya, ciri-ciri fisik-biologis yang ada pada laki-laki menjadikan ia dilihat lebih kuat dan hal itu juga kemudian mencirikan identitas mental yang agresif, rasional, dan dinamis. Karena laki-laki dianggap lebih kuat dan rasional, tugas dan pekerjaan kesehariannya didorong untuk berada di lingkungan luar rumah tangga (domain public); sementara perempuan yang lemah dan emosional berbagai kegiatannya mesti berlangsung dalam lingkungan rumah tangga (domain domestic). Dengan kata lain, pekerjaan laki-laki lebih banyak berkaitan dengan aktivitas-aktivitas produktif, salah satunya mencari nafkah, sedangkan perempuan mengerjakan tugas-tugas konsumtif, mengolah dan mengelola hal-hal yang didapat dari hasil pekerjaan laki-laki.

Masyarakat pun memiliki pembenarannya, bahwa pemisahan itu bukan perbedaan diametris yang bertentangan atau berkonflik, melainkan berhubungan secara fungsional dan saling mendukung. Dengan kata lain, pembagian kerja seksual (division of sexual labour) tersebut dipandang bukan suatu segregasi yang diskriminatif, tapi pembagian kerja fungsional yang komplementer, yang saling melengkapi, yang sesuai dengan keadaan kodrati masing-masing, sehingga satu sama lain tidak bertolak belakang dan terpisahkan. Dalam tataran filosofis, keyakinan masyarakat yang demikian itu berlandaskan pada esensialisme, suatu faham yang meyakini bahwa femininitas yang melekat pada perempuan dan maskulinitas yang ada pada laki-laki serta pemisahan aktivitas sosial, ekonomi, dan politik yang mengikuti perbedaan ciri-ciri tersebut dianggap sebagai alamiah dan kekal (Suryakusumah, 1991: 9-11).

\section{RELASI FUNGSIONAL}

Menurut pendekatan fungsionalisme-struktural dalam ilmu-ilmu sosial, sejarah mengenai terbentuknya pembagian kerja seksual antara laki-laki dan perempuan juga tidak perlu dipersoalkan, selama pembagian kerja tersebut fungsional untuk kelestarian keluarga dan masyarakat secara keseluruhan (Saptari dan Holzner, 1996: 66). Tidak perlu dipertanyakan, apakah pembagian kerja itu adil atau tidak. Tak perlu banyak dikomentari, apakah dengan adanya pembagian kerja seksual itu ada yang diuntungkan atau dirugikan. Pembagian kerja seksual yang meletakkan perempuan pada peranan ekspresif, yang mengurus struktur internal dan fungsifungsi dalam keluarga, dan laki-laki pada peranan instrumental, yang mesti mengurus hubungan antara keluarga dan masyarakat yang lebih luas, tidak perlu 
dimasalahkan keberadaannya. Yang penting sistem itu bisa menjaga integrasi masyarakat.

Dengan demikian, pembagian kerja seperti itu oleh teori fungsionalismestruktural dilihat saling melengkapi. Kepuasan yang satu akan memuaskan yang lainnya, dan karena itu akan saling memperkuat. Dengan pengaturan yang jelas bahwa perempuan harus bekerja di dalam rumah tangga dan laki-laki di luar rumah tangga, maka akan ditiadakan kemungkinan untuk terjadinya persaingan antara suami dan istri. Kalaupun istri atau perempuan diperbolehkan bekerja di luar rumah, kegiatan itu bukan merupakan karir dalam sebagian perjalanan hidupnya. Kalau tidak demikian, persaingan antara suami dan istri atau laki-laki dan perempuan akan terjadi, dan ini akan merusak keserasian kehidupan perkawinan dan rumah tangga. Pembagian kerja secara seksual memperjelas fungsi dan peran suami dan istri dalam keluarga dan hal ini akan memberikan rasa tenang bagi keduanya dan bahkan juga untuk masyarakat luas (Budiman, 1981: 18).

Di samping itu, diakui pula bahwa ada sifat-sifat kodrati pada diri perempuan yang berkaitan dengan hal-hal psikologis. Mengapa perempuan lebih banyak bergerak di domain domestik, karena perempuan memang makhluk yang pasif dan permisif yang pada dirinya melekat perasaan penuh kasih sayang, katakanlah memiliki sifat-sifat keibuan. Teori tentang sifat-sifat keibuan (mothering) pada perempuan ini menunjukkan, bahwa memang pada perempuan ada unsur psikologis internal yang membuatnya dengan rasa sukarela melestarikan kepercayaan masyarakat tentang peranan perempuan yang lebih banyak mencurahkan kemampuan dan tenaganya dalam rumah tangga. Dengan kata lain, dinyatakan oleh teori ini, bahwa posisi dan aktivitas perempuan dalam rumah tangga dianggap sebagai sesuatu yang alamiah (natura), karena melekat pada emosi diri perempuan itu sendiri; sebaliknya, laki-laki tidak memiliki sifat-sifat yang seperti itu, sehingga dengan sendirinya ia akan banyak bergerak di domain publik (Chodorow, 1983).

\section{SEKS DAN GENDER}

Dalam pandangan fungsionalisme-struktural (Budiman, 1981: 19), perempuan dan laki-laki memiliki karakteristik emosi atau kepribadian dan posisi sosial yang berbeda sejak dilahirkan, dan perbedaan itu dianggap sesuatu yang given, sudah melekat dengan sendirinya. Seorang laki-laki, karena ia berjenis kelamin laki-laki, dianggap memiliki sifat-sifat yang maskulin, seperti jantan (macho), agresif, rasional, terbuka, serta aktif dan dinamis, sehingga dengan sendirinya akan menempati posisi sosial di domain publik; sedangkan perempuan, karena jenis kelaminnya perempuan akan memiliki sifat-sifat feminin yang cenderung irasional, mendahulukan pertimbangan emosi, permisif dan pasif, serta lebih tertutup, dan karakteristik tersebut akan mengakibatkan ia menempati domain domestik.

Sesungguhnya, tesis fungsionalisme-struktural tersebut menampakkan ketidakjelasan. Keserasian masyarakat dan pembagian kerja seksual kadang- 
kadang dikatakan sebagai sesuatu yang terberi secara wajar; tetapi kadangkadang dikatakan juga sebagai sesuatu yang diperlukan, jadi diciptakan oleh manusia. Dalam konteks masalah itu, mana yang benar: apakah keserasian dalam masyarakat itu sudah ada sebelumnya, dan tingkah laku manusia hanyalah unsur dari keserasian itu; atau manusia yang yang menciptakan keserasian masyarakat melalui tingkah lakunya tersebut? Bila yang pertama yang benar, berarti teori fungsionalisme-struktural melihat manusia sebagai makhluk yang pasif, yang sekedar alat dari sesuatu yang lebih besar, yakni keserasian dalam hidup masyarakat, manusia hanya robot, yang tak punya akal dan emosi, yang sepenuhnya berada dalam pengendalian eksternal. Di sinilah teori fungfsionalismestruktural mengalami kesulitan untuk bisa menjelaskan mengapa dan bagaimana sebuah masyarakat dapat berubah dari satu tahap ke tahap yang lain atau dari satu bentuk ke bentuk yang lain, dan bahkan suatu perubahan yang bisa berlangsung dengan sangat radikal dan cepat seperti dalam revolusi, kalau semua tingkah laku manusia cuma isntrumen dari keserasian masyarakat. Kalau manusia, termasuk perempuan, tercengkeram oleh kontrol di luar dirinya, kenapa kemudian di antara perempuan ada yang melakukan gerakan yang menuntut agar diri mereka diberi peluang dan posisi yang sama dengan laki-laki. Tetapi, kalau yang kedua yang benar, maka berarti perempuan yang dikorbankan dalam kehidupan masyarakat, disubordinasikan, oleh karena sekedar diberi pekerjaan yang tidak mengembangkan potensi dirinya sebagai manusia, dengan tujuan supaya keserasian dalam hidup bermasyarakat bisa tercipta (Berry, dkk., 1999).

Sementara pertanyaan untuk teori sifat-sifat keibuan, apakah memang femininitas itu sesuatu yang juga kodrati secara psikologis? Mengapa kita bisa menemukan laki-laki yang katakanlah memiliki karakter feminin dan perempuan yang mempunyai sifat-sifat maskulin, apakah ciri-ciri yang sebaliknya itu merupakan sesuatu yang abnormal?

Suatu kritik representatif yang diajukan pada pembedaan karakteristik psikologis dan posisi sosial laki-laki dan perempuan sebagai bawaan itu, menyebutkan bahwa memang saat lahir bayi sudah memiliki kelamin (sex), lakilaki atau perempuan, tetapi belum memiliki kejeniskelaminan (gender). Karena pengaitan dengan ciri-ciri tertentulah, maka kemudian pembedaan biologis itu kelak memberi kejeniskelaminan pada manusia dan corak kepribadian tertentu. Jadi kejeniskelaminan tersebut bukanlah bawaan biologis, tetapi dikonstruksikan oleh masyarakat sendiri.

Pengkaitan atas citra laki-laki dan perempuan itu selanjutnya menggiring ke arah perbedaan jenis kelamin dalam proses pengasuhan atau sosialisasi dalam keluarga dan pembedaan maupun penandaan peran dalam masyarakat Berry, dkk., 1991: 118). Maskulinitas dan femininitas adalah stereotype yang memang didasarkan atas perbedaan biologis, tetapi bukan sesuatu yang sudah ada sejak lahir, ia merupakan suatu konstruksi kultural, dibuat oleh kebudayaan. Oleh karena itu, perbedaan tersebut lebih merujuk pada perbedaan gender, yaitu keadaan di mana individu yang lahir secara biologis sebagai laki-laki dan perempuan yang 
kemudian memperoleh pencirian mental dan sosial sebagai laki-laki dan perempuan melalui atribut-atribut maskulinitas dan feministas serta posisi dan aktivitas sosial, ekonomi, dan politik yang terpisah, yang kemudian pembedaan itu didukung atau dilegitimasi juga oleh nilai atau sistem simbol kultural masyarakat dan lebih mendasarnya lagi oleh doktrin agama (Moore, 1988: 13-14).

Perbedaan jenis kelamin dianggap hanya bersangkut-paut dengan perbedaan dalam ciri-ciri biologis, terutama yang berkaitan dengan persoalan prokreasi (hamil, melahirkan, dan menyusui), sementara perbedaan gender adalah perbedaan simbolis dan sosial yang memang berpangkal pada perbedaan seks, tetapi tidak selalu identik dengannya. Citra perempuan yang lembut, halus, permisif, emosional adalah suatu askriptif gender, sebuah kategori yang merefleksikan askripsi sosial dari jenis kelamin tertentu umpamanya dalam konteks peran reproduktif dan posisi ekonomi (1992: 119). Melalui askriptif gender inilah sebenarnya sistem patriarkhi bermula dan kemudian dimapankan keberlakuannya, yang ditandai oleh adanya hubungan asimetris antara laki-laki dan perempuan, laki-laki menempati kedudukan yang lebih unggul daripada perempuan baik di domestic domain (di dalam rumah tangga sebagai kepala keluarga) maupun di public domain (di luar rumah tangga sebagai pencari nafkah).

Secara subtansial, keasimetrisan hubungan antara laki-laki dan perempuan itu bersifat umum, meskipun bentuk dan wilayah pengekspresiannya berbeda secara lintas budaya (Truong, 1992: 110). Dalam sistem kekerabatan matrilineal umpamanya, yang menarik garis keturunan dari pihak perempuan, ternyata posisi perempuan tidaklah superior. Sebagai contoh, kedudukan perempuan di Sumatra Barat selalu dikaitkan secara tradisional dengan wilayah darat (center) dan laki-laki dengan rantau (periphery). Berdasarkan pembagian posisi tersebut, perempuan hanya akan memiliki status dan otoritas yang relatif tinggi bila ia berada dalam domain-nya sendiri (darat), tetapi bila ia berada dalam domain laki-laki (rantau) statusnya menjadi inferior dan memiliki otoritas yang sangat kecil (Poster-Coster, 1987: 230-233). Malah sebenarnya posisi superior perempuan di domestic domain (darat) itu sendiri boleh dikatakan cukup terbatas, karena perannya hanya pada penentuan sistem waris harta pusaka, sementara pemimpin-pemimpin masyarakat mulai dari kelompok terkecil (buah gadang) sampai kelompok yang lebih besar seperti nagari (desa) pada umumnya adalah laki-laki (Benda-Beckman, 2000: 103107).

\section{GERAKAN PEREMPUAN DAN MODERNISASI}

Pada tingkatan praktik, kritik atas bawaan biologis melihat bahwa stereotypes serta berbagai prasangka dan pemisahan sosial itu lebih banyak merugikan kaum perempuan. Terutama dengan ditempatkannya perempuan di sektor domestik, gerak perempuan menjadi sangat terbatas, padahal proses modernisasi atau perkembangan sosial-ekonomi masyarakat, terutama mulai abad ke 19 yang pada awalnya berlangsung pada masyarakat Barat, terjadi dengan pesat. Berbagai jenis teknologi masinal mulai banyak ditemukan yang menggantikan teknologi manual; 
tingkat kesejahteraan masyarakat juga naik akibat perdagangan lintas negara dan benua dan proses kolonisasi pada masyarakat-masyarakat non-Barat; pendidikkan formal juga semakin berkembang yang mendorong pada berkembangnya ilmu pengetahuan dan teknologi. Namun perubahan peradaban yang sifatnya progresif itu yang lebih banyak berlangsung di sektor publik ternyata lebih banyak dinikmati kaum laki-laki, sementara berbagai potensi yang sebenarnya juga dimiliki kaum perempuan tidak bisa muncul ke permukaan, karena gerak langkahnya sangat dibatasi, ia "dikurung" di sektor domestik yang ranah itu tidak banyak tersentuh oleh arus perubahan besar tersebut.

Mulailah kemudian sebagian kaum perempuan menuntut untuk bisa ke luar dari ranah domestik, terutama untuk bisa mengenyam pendidikan yang sama seperti yang dinikmati laki-laki. Pendidikan formal dianggap sebagai wahana atau tangga yang memungkinkan kaum perempuan bisa mengikuti arus modernisasi dan terlibat dalam perkembangan ilmu pengetahuan dan teknologi. Tetapi kaum perempuan yang menghendaki adanya perubahan itu pun menyadari, bahwa upaya emansipasi yang mereka tuntut tetap tidak akan meninggalkan berbagai tugas yang diembannya di ranah domestik. Dengan kata lain, meskipun mereka ingin dan dapat aktif di ranah publik, ranah domestik tetap akan menjadi tugas utama mereka. Inilah gerakan perempuan yang dikenal sebagai feminisme liberal (Amal, 1995: 86-88; Saptari dan Holzner, 1996: 420-422).

Pada prinsipnya, gerakan feminsime liberal ini berargumentasi, bahwa memang ada ketidakadilan dalam relasi antara laki-laki dan perempuan, dalam hubungan-hubungan itu laki-laki lebih diuntungkan. Karena itu, supaya perempuan pun memperoleh keuntungan, ia musti terlibat dalam peluang dan kesempatan kerja dan berusaha serta pendidikan yang tersedia di ranah publik. Namun demikian, emansipasi yang dituju itu tidak sampai menolak kodratinya yang memiliki sifat-sifat keibuan dan tidak meninggalkan fungsi sosial di ranah domestik. Kalaulah perempuan bekerja di sektor publik, jangan sampai ke luar dari sektor domestiknya, karena di situlah sifat keibuan dan peranan sosial perempuan tidak bisa ditinggalkan (Budiman, 1981: 42; Saptari dan Holzner, 1996: 50-52; Amal, 1995: 86-88). Mungkin apa yang dituntut dan diminta Kartini, salah seorang pejuang emansipasi perempuan Indonesia di awal abad ke 20, dapat mewakili tujuan dari gerakan feminisme liberal ini, yaitu ketika ia meminta pada ayahnya agar diberi kesempatan yang sama seperti kakak laki-lakinya untuk melanjutkan sekolah ke tingkat yang lebih tinggi, sekolah tingkat menengah di Kota Semarang, Jawa Tengah, dan menurutnya, dari hasil pendidikan sekolah itu, meskipun ia adalah seorang wanita, "ia bisa menjadi manusia sepenuhnya, tanpa berhenti menjadi wanita sepenuhnya" (Kartini, 1987: 8).

Gerakan feminisme liberal merupakan gerakan perempuan yang tertua, sudah muncul ke permukaan sejak abad ke 19 . Tapi bila dilihat dari keberhasilannya, sukses yang capainya, sampai kini masih terbatas. Kesadaran perempuan tentang perlakuan yang tidak adil atas diri mereka memang bertambah, namun tidak banyak yang berubah dalam hal memperbaiki kepincangan. Hal ini dikarenakan 
kaum feminis liberal kurang memperhatikan faktor-faktor sosial-ekonomi dan sosial-politik yang menjadi basis dan langsung mendukung keberadaan sistem patriarkhi. Semasa hidup Kartini ideologi liberalisme dan modernisme sedang hidup subur di Eropa dan Belanda sebagai bagian dari Eropa membawanya ke tanah jajahannya, Indonesia. Karena itu, wajarlah bila Kartini terpengaruh oleh pemikiran liberalisme ini.

Sampai periode tahun 1970-an, feminisme liberal ini masih cukup kuat sebagai suatu gerakan perempuan dalam menghadapi ketidakadilan dan upaya meningkatkan posisi mereka di sektor publik dan juga diterapkan dalam kebijakan negara, khususnya dalam rangka penyesuaian atas proses modernisasi dan adaptasi itu dilakukan melalui pendidikan formal. Namun demikian, konsekuensi dari pendekatan yang demikian itu, malah mengakibatkan perempuan menjadi dibebani oleh dua peran, di satu pihak ia bisa terjun di sektor publik, katakanlah menjadi perempuan yang bisa berkarir pada berbagai disiplin keilmuan dan menduduki jabatan-jabatan tertentu pada berbagai sektor pekerjaan di lembagalembaga kenegaraan dan di perusahaan-perusahaan swasta dari yang kecil sampai yang besar, di pihak lain ia pun harus tetap melaksanakan kegiatan di sektor domestik. Dengan kata lain, gerakan feminsime liberal ini mengakibatkan perempuan menjadi memiliki peran ganda. Politik pembangunan Orde Baru dalam rangka meningkatkan peran perempuan dalam pembangunan atau modernisasi banyak mengadopsi faham feminisme liberal ini, di mana perempuan diperbolehkan bersekolah setinggi mungkin dan aktif di sektor publik, tetapi sekaligus tidak diperbolehkan meninggalkan posisi sosial yang dianggap kodratnya di sektor domestik. Dengan kata lain, ia diperbolehkan menjadi perempuan karir, tapi bersamaan dengan itu harus menjadi "istri" bagi suami dan "ibu" bagi anakanaknya (Suryakusumah, 1991).

Tampaknya juga, dalam batas-batas tertentu, hingga sekarang faham ini masih menjadi kerangka acuan dalam kebijakan politik lembaga kenegaraan serta diyakini sebagian kalangan warga masyarakat, bahwa jalan terbaik untuk meningkatkan posisi perempuan di ranah publik adalah melalui pendidikan sekolah. Namun, upaya emansipasi perempuan melalui institusi sekolah itu tidak dibarengi dengan perubahan-perubahan metode dan kurikulum yang ada di sekolah tersebut, yang cenderung memperlakukan siswa perempuan lebih inferior daripada siswa laki-laki. Umpamanya melalui teks-teks bacaan pada buku-buku sekolah itu dideskripsikan posisi dan peran laki-laki sebagai pemimpin rumah tangga, direktur perusahaan, kepala badan urusan tertentu pada lembaga-lembaga pemerintahan; sementara, gambaran perempuan adalah sebagai ibu rumah tangga, yang mengurus anak dan memasak, dan kalaupun perempuan digambarkan berkiprah di ranah publik, posisi dan perannya hanya sebagai sekretaris, bendahara, atau sekedar sebagai staf yang berada di bawah posisi laki-laki, bukan sebagai pengambil keputusan strategis. Kurikulum yang menggambarkan ketidakadilan gender itu sampai kini masih menjadi bahan utama pelajaran di sekolah-sekolah tingkat dasar sampai sekolah-sekolah menengah tingkat atas. 
Kurikulum pendidikan sekolah yang demikian ini sesungguhnya lebih merupakan perluasan stereotipe dari kegiatan laki-laki dan perempuan dalam masyarakat. Implikasi dari model kurikulum ini berarti lebih menunjukkan adanya pembakuan peran sosial antara perempuan dan laki-laki, karena di situ ditekankan proses sosialisasi pengetahuan tentang pekerjaan kerumahtanggaan dan kemampuan keperempuanan lainnya ketimbang pengetahuan keilmuan dan ketrampilan teknis. Karena itu, kurikulum itu sebenarnya, secara langsung atau tidak, lebih mempersiapkan perempuan untuk bekerja di lingkungan rumah tangga. Dalam konteks persoalan itulah, pendidikan sekolah itu sendiri nampak sangat berprasangka gender dan cenderung mengekalkannya daripada menolaknya. Jadinya, pendidikan semacam itu memiliki kecenderungan untuk menghadapi kegagalan dalam mempersiapkan potensi dan kemampuan perempuan untuk bisa berkiprah dalam berbagai sektor kehidupan, terutama di lembaga-lembaga publik, kecuali perannya sebagai karyawan bawahan atau menjadi istri dan ibu. Dan karenanya, di sini bisa disimpulkan, bahwa pendidikan sekolah yang demikian itu, yang bergabung dengan prasangka-prasangka umum mengenai inferioritas perempuan, malah kian memperkuat keyakinan mengenai adanya perbedaan pembawaan sejak lahir dalam kemampuan-kemampuan kedua jenis kelamin.

\section{POSMODERNISME SEBAGAI KRITIK}

Feminisme liberal dalam landasan wacana gerakannya tidak banyak menyentuh ideologi patriarkhi. Tidak ada upaya untuk mendobrak, atau memakai istilah posmodernisme, mendekonstruksi ideologi patriarkhi yang menempatkan laki-laki sebagai "pemimpin" perempuan. Gerakan emansipasi feminisme liberal hanya terarah pada usaha untuk meningkatkan posisi sosial diri perempuan, sementara ideologi dan struktur yang menjadi akar dari ketidakadilan itu tidak diusahakan untuk diubah. Dalam konteks inilah, kenapa produk dari gerakan feminisme liberal malah membebani perempuan dengan peran gandanya, sementara posisi laki-laki tetap tidak tergoyahkan.

Kegagalan feminisme liberal dimungkinkan karena ia terlalu berlebihan mempercayai proses modernisasi, khususnya melalui pendidikan formal, sebagai wahana yang dapat mendorong perwujudan emansipasi. Padahal modernisasi sebagai suatu faham, modernisme, dengan segala atribut yang ada di dalamnya, ternyata telah gagal dalam beberapa hal penting. Ada semacam keyakinan - yang sesungguhnya tidak banyak berdasar - bahwa ilmu pengetahuan dan teknologi modern mampu memecahkan segala persoalan yang dihadapi manusia dan lingkungannya. Keyakinan ini keliru manakala kita menyaksikan bahwa kelaparan, kemiskinan, ketimpangan gender, dan kerusakan lingkungan terus terjadi yang menyertai perkembangan ilmu pengetahuan dan teknologi tersebut (Hadiwinata, 1994: 23). Dalam konteks kegagalan modernisme inilah, kemudian muncul pendekatan posmodernisme yang berusaha mendekonstruksi secara radikal wacana (discourse) mengenai relasi antara laki-laki dan perempuan. Menurut 
posmodernisme, posisi perempuan yang tersubordinasi tersebut merupakan hasil praktek diskursif pada berbagai bidang, seperti seksualitas, agama, politik, sosialkebudayaan, ekonomi, serta ilmu pengetahuan dan teknologi, yang kesemua bidang itu "dikuasai" wacana kelaki-lakian, sehingga wacana dan gerakan apa pun yang diungkapkan perempuan mesti akan terjebak ke dalam wacana praktek diskursif itu (Saptari dan Holzner, 1996: 78-82).

Apa yang disebut wacana memang berkaitan dengan bahasa, tetapi bahasa ini tidak dilihat hanya sebagai alat atau sekedar prosedur yang memiliki fungsi teknis untuk keperluan bertukar gagasan atau dialog. Bahasa diletakkan sebagai hal yang strategis dalam formasi pengetahuan dan kekuasaan dalam hubunganhubungan antar manusia (Heryanto, 1994: 84). Bahasa adalah alat kekuasaan, tetapi sekaligus juga produk kekuasaan, jadi bahasa dan kekuasaan ini menyatu. Sementara itu, dalam perjalanan historis masyarakat, perkembangan masyarakat ini bisa dikuasai oleh laki-laki, yang salah produknya adalah ilmu pengetahuan. Ilmu pengetahuan sebagai produk dari wacana tentang kekuasaan laki-laki ini bercirikan: pertama, gairahnya pada stabilitas dan kecenderungannya untuk menjelaskan segala sesuatu lewat hukum-hukum kodrat; kedua, anggapan tentang ilmu pengetahuan dan filsafat adalah untuk mencapai hal-hal yang obyektif dan kemudian mengklaim diri sebagai dasar pengetahuan yang universal; ketiga, sikap mencari kebenaran dan pengetahuan mesti dianggap tidak berubah, atau juga dianggap universal; keempat, akal (reason) itu sendiri dipandang sebagai sesuatu yang bersifat transendental dan mempunyai kualitas universal: yang ada (being) dianggap terpisah sudah dengan sendirinya, bukan karena dinamika historis; pengalaman sosial dianggap tidak berhubungan dengan struktur pemikiran; tidak memandang pengetahuan sebagai produk yang bersifat sementara; dan kelima, bahasa, dalam hal tertentu dianggap transparan, seperti akal, bahasa tampil mewakili yang real, bahasa hanya dianggap sebagai medium di mana representasi hadir, diandaikan terdapat kesamaan antara kata dengan obyek, obyek/realitas tidak dianggap dikonstruksi secara sosial (Arivia, 1993: 33).

Dalam konteks wacana kekuasaan laki-laki itulah, gerakan feminisme pertama-tama dan yang paling utama adalah mendekontruksi wacana grand narrative atau pemikiran logosentrik yang demikian itu. Jangan sekali-kali gerakan perempuan berada di dalam atau menggunakan wacana umum kalau produknya tidak ingin seperti feminisme liberal, yang pada akhirnya tetap memojokkan dan bahkan semakin membebani perempuan melalui peran gandanya. Wacana yang dikembangkan gerakan perempuan harus dekonstruktif, yakni adanya keinginan untuk skeptis atas segala bentuk kepercayaan pada kebenaran mutlak, pengetahuan, kekuasaan, dan bahasa, dan melihat bahwa itu semua sifatnya hanyalah representatif dan politis bagi kepentingan laki-laki sebagai kelompok dominant (Arivia, 1993: 33).

Dengan demikian gerakan feminisme yang berorientasi posmodernisme, pertama-tama harus selalu "mecurigai" bentuk wacana dan berbagai praktek diskursifnya. Kedua, mendekonstruksi wacana tentang kelaki-lakian dan 
keperempuanan, baik dari sisi teksnya, kebahasaannya, maupun dari hubunganhubungan kuasanya; dengan kata lain, perempuan harus melakukan "penolakan" kritis atas sistem relasi gender yang terartikulasikan lewat bahasa, yang sebenarnya menunjuk pada ideologi dan praktek patriarkhi. Dan ketiga, memulai pergerakan dengan mengembangkan eks-sentralisme yang mengungkapkan bahwa perempuan memiliki logika sendiri, perspektif sendiri, dan dapat mengkonstruksikan wacananya sendiri (Arivia, 1993: 32). Secara umum, di sini gerakan perempuan harus tidak mengakui dan sama sekali atau menolak wacana dan hubungan kekuasaan yang berlangsung dalam masyarakat, dan kemudian membangun relasi kekuasaan melalui pengetahuan-pengetahuan yang diungkapkan yang merupakan produk perempuan. Membangun relasi kuasa yang di dalamnya melibatkan wacana pengetahuan yang juga diproduksi perempuan itu dimungkinkan karena, dengan meminjam konsep kekuasaan dari Michel Foucault, kekuasaan itu ada di mana-mana dan dimiliki siapa pun; individu atau sekecil apa pun kelompok masyarakat, termasuk perempuan, pasti memiliki kekuasaan dan kekuasaan yang dipunyai perempuan itu harus dimanfaatkan untuk mendekonstruksi wacana dan membangun relasi-relasi kekuasaan baru yang di dalam relasi itu "suara" perempuan bukan hanya terdengar, tetapi hidup di dalam praktek diskursif. Melalui dekonstruksi pada wacana dan praktek diskursif yang melibatkan perempuan itulah, akan tampak keberadaan perempuan sebagai manusia yang utuh, yang berbeda dengan laki-laki, tetapi perbedaan itu tidak menunjuk pada struktur kekuasaan yang hirarkhis dan patriarkhis, tetapi suatu relasi kekuasaan yang egaliter (Truong, 1992: 120-121).

\section{REFLEKSI}

Betapa tidak membingungkan bila salah satu kesibukan posmodernisme adalah meragukan berbagai kepastian yang dikeramatkan dalam masyarakat. Atau dengan kata lain, posmodernisme mencoba membuka berbagai kemungkinan yang semula dianggap tidak masuk akal, mustahil, atau tabu. Katakanlah, ia pejuang keterbukaan yang sangat radikal, termasuk keterbukaan bagi hal-hal yang belum kita ketahui keberadaannya secara serba pasti (Heriyanto, 1994: 83). Sementara kita selama ini sudah dijejali dan telah melekat dalam kerangka berpikir kita, bahwa sesuatu yang ada itu harus konsisten, logis, formal, metodis dan sistematis, punya basis, ada dalam keseimbangan, terintegrasi, dan bila pun sesuatu itu plural bagian-bagiannya harus berhubungan secara fungsional.

Jadi yang membingungkan adalah adanya cara berpikir yang menolak dengan begitu mendasar usaha-usaha konstruktif dalam menempatkan manusia ke dalam posisi asasinya. Bahkan mereka mendekonstruksi dan mendeformasi upaya-upaya yang telah dan sedang dibangun. Apakah karena mereka tidak memiliki kepercayaan akan adanya prinsip-prinsip dasar yang mengatur perjalanan hidup manusia? Kenapa mereka malah kemudian meletakkan manusia dalam posisi yang begitu marginal dan marginalitas itu dianggap sebagai produk dari berbagai konstruksi historis sosial dan budaya, atau malah ekstremnya sekedar refleksi 
wacana kebahasaan. Sudah pasti kita akan dibingungkan dengan berbagai pertanyaan itu, tetapi tentunya bila kita selama ini berada dalam kerangka berpikir historis-linier, dogmatis-absolut atau hitam-putih, dan penekanan secara ketat pada prinsip-prinisp rasionalitas.

Tetapi memang kita akan dibuat bingung. Betapa tidak! Rasionalitas yang memang pada dirinya memiliki sifat-sifat yang stabil, harus dibongkar, padahal rasionalitas manusia ini sudah menghasilkan, umpamanya ragam teknologi yang beroperasi dengan tingkat presisi tinggi. Apa jadinya bila rasionalitas harus dikesampingkan, bisakah teknologi beroperasi tanpa memperhitungkan prinsipprinsip rasionalitas? Tidakkah mungkin upaya-upaya pembongkaran prinsip-prinsip rasionalitas ini akan mendorong pada pemikiran yang anarkhistik, dan bahkan nihilistik?

Dalam kaitannya dengan persoalan perempuan, mungkin pertanyaanpertanyaan yang bisa diajukan pada aliran posmodernisme ini: seperti apakah wacana yang berlandaskan dan berorientasi perempuan itu? Apakah memang wacana yang selama ini berkembang tidak melibatkan perempuan alias sepenuhnya dikuasai laki-laki? Wacana kekuasaan seperti apa yang dimiliki perempuan itu? Sudah adakah wacana itu? Apakah memang perempuan memiliki wacana tersendiri yang begitu berbeda dengan wacana yang dimiliki laki-laki? Dalam bentuk dan substansi seperti apa perbedaan wacana tersebut? Mungkin itulah pertanyaan-pertanyaan yang cukup mendasar yang bisa diajukan pada gerakan feminisme yang berorientasi posmodernisme.

Namun pada intinya, gerakan perempuan yang berorientasi posmodernisme itu melihat bahwa ada "kekhususan" atau katakanlah potensi pada diri dan posisi perempuan dalam masyarakat itu. Dan kekhususan yang ada tersebut perlulah dihormati dan diberi ruang untuk lebih berkembang, bukannya dilecehkan dan disubordinasikan. Sediakan ruang-ruang yang lebih terbuka agar potensi yang dimiliki perempuan itu bisa terdengar dan terartikulasikan sebagai suara dan wacana, dan bahkan menjadi praktek hidup sehari-hari, yang memang berasal dari perempuan itu sendiri, bukan yang berasal dari representasi ideologi patriarkhis. Di sinilah posmodernisme sebagai piranti berpikir dan program strategis menjadi memiliki makna yang berarti untuk penguatan posisi dan peran perempuan dalam relasi gender yang tidak hirarkhis.

\section{DAFTAR PUSTAKA}

Amal, Siti Hidayati. (1995). "Beberapa Perspektif Feminis dalam Menganalisis Permasalahan Wanita," dalam T.O. Ihromi (Penyunting), Kajian Wanita dalam Pembangunan. Jakarta: Yayasan Obor Indonesia.

Arivia, Gadis. (1993). "Feminisme Pascaramodernis." Prisma, No. 1, Tahun XXII.

Benda-Beckman, Keebet von. (2000). Goyahnya Tangga Menuju Mufakat. Jakarta: Gramedia.

Berry, dkk. (1999). Psikologi Lintas-Budaya; Riset dan Aplikasi. Jakarta: Gramedia. 
Budiman, Arief. (1981). Pembagian Kerja Seksual. Jakarta: Gramedia.

Chodorow, Nancy. (1983). "Family Structure and Feminine Personality," dalam Rosaldo and Lamphere (Eds). Women, Culture, and Society. Stanford: Stanford University Press.

Cohen, Percy C. (1979). Modern Social Theory. London: The English Langguage Book Society.

Hadiwinata, Bob Sugeng. (1994). "Theatrum Politicum." Kalam, Edisi 1.

Heryanto, Ariel. (1994). "Posmodernisme yang Mana? Kalam, edisi 1.

Kartini. (1987). Surat-surat kepada Ny. R. M. Abendanon-Mandri dan Suaminya. Jakarta: Penerbit Djambatan.

Moore, Henrietta L. (1988). Feminism and Anthropology. London: Polity Press.

Poster-Coster, Els. (1987). "The Image of Women in Minangkabau Fiction." dalam Elsbeth Locher-Scholten and Anke Niehof, Indonesian Women in Focus. DordrechtHolland: Foris Publications.

Saptari, Ratna dan Brigitte Holzner. (1996). Perempuan, Kerja, dan Perubahan Sosial. Jakarta: Grafiti Pers.

Suryakusumah, Julia I. (1991). "Seksualitas dalam Pengaturan Negara." Prisma, No. 7, Tahun XX.

Suryakusumah, Julia I. (1991). "Konstruksi Sosial Seksualitas; sebuah Pengantar Teoritis." Prisma, No. 7, Tahun XX.

Thanh-Dam, Truong. (1992). Seks, Uang, dan Kekuasaan; Pariwisata dan Pelacuran di Asia Tenggara. Jakarta: LP3ES. 